\title{
THE LONELINESS OF THE LONG-DISTANCE PANDA
}

\section{Bear necessities.}

\section{BY JACEY BEDFORD}

$\mathrm{T}$ There were no two ways about it: he clunked when he walked. It was the near hind that was causing the problem. He'd noticed it days ago, soon after crossing the Bering Strait, some 85 relentless kilometres of icy salt water. Pad, pad, pad, clunk. Pad, pad, pad, clunk. Yes, definitely the hip. Too much exercise and way too much salt water.

He'd not been made for this kind of travel, just a little gentle shuffling between bamboo groves, avoiding too many ups and downs. He'd heard them talking about him in the lab before he was released. A bear, they'd called him, Ailuropoda melanoleuca, black and white cat-foot, a living fossil. They said his closest ursine relative was the spectacled bear of South America, Tremarctos ornatus. He'd checked his GPS, still functioning after all this time, and pondered in the manner of his kind. China to South America was a long walk for a panda, but he could do it if he had to.

It had been many years since he'd walked out of the Qinling Mountains in hilly Sichuan Province and set off to find more of his kind, but although he'd walked north though China to Siberia, he'd found no organic creature larger than a cockroach and no one like himself. He didn't know what had happened to his makers, but it must have happened a long time ago. They'd gone the way of the panda at last.

Back in the early twenty-first century, the International Union for Conservation of Nature had declared his species as endangered and conservation reliant, but hadn't followed through until it was too late. Maybe they'd thought it enough that the giant panda genome had been sequenced in 2009 , but it took more than that to keep a whole species viable. It took bamboo and more bamboo and the resources shrank each year.

That's when they'd made him and others like him. Giant pandas, able to live in the wild on fresh air - a sop to national pride. Something for the tourists to gawp at, perfect in all respects, on the outside at least. On the inside, however, their hearts were tiny fusion reactors; their skeletons, foam-metal; their joints, ceramic; and their muscles, skin and fur woven from various polymers.

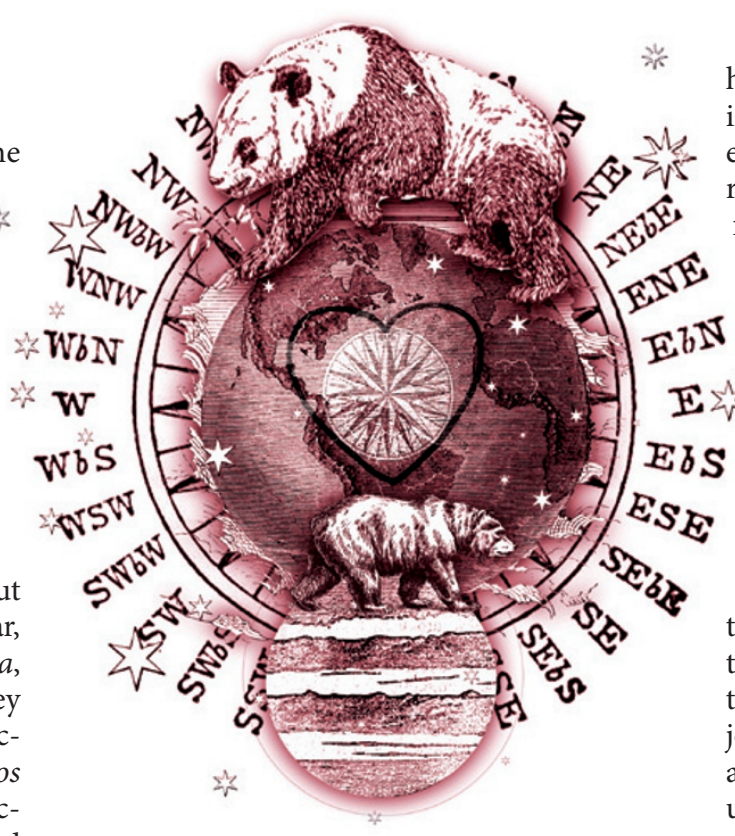

He could access his internal clock if he really wanted to and find out how long it had been since the others ceased to function. He was the last of his kind, and pretty soon he'd be unable to walk. Pad, pad, pad, clunk! What would happen then? He imagined himself stranded in this land of glaciers. How long would it take for his fuel cell to run down? Too long. He wondered if it was possible for a creature like him to go mad.

Alaska's broken coastline caused him detour after detour and he stopped checking his clock, fearful of seeing years pass while he relentlessly plodded south. Always south. Pad, pad, pad, clunk through Alaska and British Columbia until the pad, pad, pad, clunk became pad, pad, clank, clunk.

He had to skirt an active volcano where Seattle used to be. Its rumbling and occasional belch of acrid smoke set off his alarm systems and the volcanic grit irritated his retractable claw beds, causing him delays for cleaning and maintenance. Pad, pad, clank, clunk became pad, pad, clank-drag and he was grateful when he reached the benign forests of Oregon.

$\rightarrow$ NATURE.COM

Follow Futures on

Facebook at:

go.nature.com/mtoodm
He was resting his rear hind servo when he heard a whine above him and felt the sudden tug of an antigrav hauler. He was whisked up to a laboratory in the sky. Surprise wasn't one of his inbuilt emotions and he knew all about laboratories, even alien ones, so he settled down feeling only mild curiosity. They shot him with a cryo-anaesthetic that might have worked if he'd been organic, or might have killed him, as the aliens, themselves crystalline blobs, seemed to know so little of Earth-based physiology that they couldn't tell the difference between biological and mechanical. At least they didn't seem interested in taking him apart to see how he worked.

He lay awake for the 90 years it took for their ark ship to return home, grateful that the enforced rest gave his depleted nanites time to repair most of the damage to his hip joints. Occasionally he would open one eye and watch the aliens at work, gleaning an understanding of their communications system, a mixture of audible sounds and electronic impulses. They never seemed to figure out his recorded system responses, though, which were in Mandarin.

In the alien zoo they gave him a huge enclosure that exactly replicated the forest they'd found him in, and put up a communication repeater that he deciphered as Dominant species of Planet 40698-C. He shrugged and methodically deleted his GPS database to make room for new information, then set off in a southerly direction. Pad, pad, pad, clink.

He found her on the fourth day, staring round-eyed and hopeful from the lower branches of a tall tree. He'd walked up one side of Earth and back down again to find another of his kind, and here she was, halfway round the galaxy in an alien zoo. From her black coat to her lighter eye markings, she was a prime example of the spectacled bear of South America. He dipped his head in acknowledgement and she dipped hers in return. She climbed down her tree and walked towards him shyly. The faint sound of her servos, pad-clunk, pad, pad, drifted towards him and it made his little fusion reactor glad within his breast.

Jacey Bedford lives on the Yorkshire Pennines with her songwriter husband, and is trying to get all the stories in her head down on paper before her brain explodes. 